\title{
Proposed Relief Map of the Suitability of the Maranhão River Basin, Brazil, for Anthropogenic Use
}

\author{
Valdir A. Steinke*, Ercilia Torres Steinke, Mario Diniz Araujo Neto, \\ Maria Ligia Cassol Pinto \\ University of Brasilia, Brasília, Brazil \\ Email: *valdirsteinke@gmail.com
}

Received 9 April 2016; accepted 3 June 2016; published 6 June 2016

Copyright (C) 2016 by authors and Scientific Research Publishing Inc. This work is licensed under the Creative Commons Attribution International License (CC BY). http://creativecommons.org/licenses/by/4.0/

\begin{abstract}
In this paper, we proposed a method for mapping the suitability of land for intensive anthropogenic use in the Maranhão River Basin, in the state of Goiás, Brazil. We analyzed existing 1:250,000 maps of the local geology, drainage system topography and geomorphological features. We generated new information based on our analysis, including a compilation of basic morphometric data and a map of the slopes in the basin, which we used to construct the geomorphological suitability map of the watershed. Our results indicate that $40 \%$ of the study area can support intensive anthropogenic use; the remaining $60 \%$ of the basin area is categorized as "fragile" regarding the expansion of intensive land use.
\end{abstract}

\section{Keywords}

Morphometry, GIS, Environmental Management, Suitability of the Watershed, Land Use Policy

\section{Introduction}

Geomorphological studies have helped researchers understand topographical relief. According to [1], the main objective of geomorphology is to analyze various forms of relief to understand the relationship between past and present processes. Understanding of local relief and the processes that shape, it is important when seeking to responsibly utilize natural resources with minimal damage to the environment. According to [2], a river system results from the sculpting of active processes that result in a change in relief. Such systems should be studied and analyzed because their formation is "the most active morphogenetic process in sculpting the Earth's land-

*Corresponding author.

How to cite this paper: Steinke, V.A., Steinke, E.T., Neto, M.D.A. and Pinto, M.L.C. (2016) Proposed Relief Map of the Suitability of the Maranhão River Basin, Brazil, for Anthropogenic Use. Journal of Geographic Information System, 8, 351-360. http://dx.doi.org/10.4236/igis.2016.83030 
scape".

It is important to analyze and understand a watershed's morphology not only because of its role in the area's geomorphology but also because watersheds are treated as major geographical units for planning and geo-environmental analysis in Brazil. Morphometric analysis can help determine the capabilities and constraints of a watershed and its suitability for various anthropogenic uses.

In this study, fitness is defined as the capacity of relief to support human activities while minimizing the impact on the watershed. Thus, studying the geomorphological characteristics of a watershed has implications for its occupation and the use and management of its natural resources. The geomorphological characteristics of watersheds are instrumental for academic research and land use planning.

The hydrological behavior of a watershed [3] is determined by its morphological characteristics. To understand the relationships between the hydrological processes in a basin, their features must be expressed quantitatively. Quantitative analysis of morphometric parameters can be useful in assessing watersheds for proper management, conserving natural resources, and supporting the most appropriate uses of their land and water. According to [4], morphometric analysis provides a quantitative description of a drainage system, which is one of the most important aspects when characterizing a watershed.

[5] finds that the organization of a drainage system largely reflects the complexity of its development and evolution and results from interactions between the local climate, lithology and tectonics. Understanding this organization is important for environmental management and especially the "planned land use, for which the influence of anthropogenic changes in land use and climate on the watershed must be predicted" [6]. Following drainage morphometry studies by [4] [7]-[11], many studies have used this method to characterize river basins and sub-basins in different geographical regions.

In this sense, morphometric analysis can be considered an essential tool for the qualification of a watershed. The proper interpretation of a drainage network, including the local geology and morphology, can reveal numerous issues related to erosion, which is the principal element of physiographic and geomorphological processes [2].

Morphometric analysis assumes that quantitative data can serve as parameters for the physical qualification of the basin and its hydrosedimentological processes, characterizing them precisely and revealing their homogeneity, according to [12]. Thus, variables related to the length, height, width, volume, gradient, density, and frequency are used for vulnerability assessments from an environmental geomorphology perspective.

Given the current demand for water resources and growing concern about environmental problems at the local, regional and global scales, morphometric studies can play an important role in consistently characterizing watersheds. Thus, they can support integrated management by quantitatively describing the complex landscapes contained in a drainage basin.

Relief features have cartographic elements that are present in various sizes and shapes. Characterizing the sizes and shapes of these features is important in understanding their genesis and current dynamics, and their cartographic representation allows synthesizing their roles in a landscape. Therefore, geomorphological mapping and classification has been the subject of research and experimentation since the 1960s in various countries, particularly in Europe [13].

Different land uses (rural, agricultural, industrial and urban) in plains or on hillslopes are elements in a basin's landscape and scenery. They can have various negative environmental impacts, including vegetation removal, pollution, and silting. Human activities occur at a higher intensity in urban areas because of the concentration and variety of economic activities in such locations that result in the degradation of natural resources [14].

Geomorphological mapping should consider both taxonomy and scale and aim to characterize various types of relief, grouping them into different classes. In general, maps can be presented as morphostructural domains, geomorphologic regions, geomorphologic units and model types [15].

When studying relief based on geomorphological units, model types and forms, it should be noted that other elements of the geomorphological system might require special attention. In particular, hydrographic information on land slope and morphometric drainage is important, including relief dissection parameters, such as drainage density, split ratios and the average length of channels. This set of morphometric parameters can be grouped into classes based on the different patterns of the existing relief in a certain geomorphological region.

A morphometric analysis of relief can also help subdivide it into different geomorphological units [16]. Conducted a survey in which the morphometric analysis of the Passa Cinco (SP) river basin allowed the identification of five major geomorphological units. Their methodology was based on the previous studies of slope [17]; 
[18], horizontal dissection [19]; [20], vertical dissection, relief [21], and density and depth of dissection [22]. Their results showed that morphometric analysis can also facilitate understanding the morphological structure of relief and allow for more extensive descriptions of the shapes, ages and genesis of relief.

Therefore, geomorphological characterization is a fundamental basis for environmental studies. This study aimed to analyze morphometric variables in the Maranhão River Basin (DF-GO), Brazil and indicate its geomorphological suitability for various anthropogenic uses.

The mapping studies have used mapping studies of individualized form without the adequate incorporation of morphometric elements with the proposals of public policies for zoning of the territory. So in this text there is the proposal to analyze the potential of morphometric information for methodological advances in land planning policies.

\section{Materials and Methods}

The Maranhão River Basin is an important unit of study because it covers two states (Goiás and Tocantins) and the Distrito Federal in mid western Brazil. In addition, it is an important catchment area of the Araguaia- Tocantins water system (Figure 1). The river's source is in Brazil's Central Plateau and Brasília City. A significant portion of the basin's headwaters is located in the Environmental Protection Area (APA) of the Cafuringa and Emendadas Water Ecological Station [23]. In January 2002, another portion of the Maranhão River Basin was added to the Central Plateau APA (Federal Decree No. 9468 on 10 January 2002).

This study used drainage and topography data from 1:250,000 maps to conduct a basic morphometric analysis of the basin. All calculations to identify the morphometric indicators followed the recommendations and equations proposed by [2] [4] [8] [24], which are widely accepted in the literature. The quantities used in this work were the bifurcation ratio $\left(R_{b}\right)$, drainage density $\left(D_{d}\right)$, river density $\left(D_{r}\right)$, extension of the path surface $\left(E_{p s}\right)$, basin area $(A)$, basin length $(L)$, ratio of the average length between two subsequent orders (MLR), and channel tortuosity index $\left(I_{s}\right)$.

The split ratio (LR) is the ratio of the total number of channels in a certain order and the total number of channels in the order immediately above. This ratio must be constant and can never be less than 2 [25]. It is

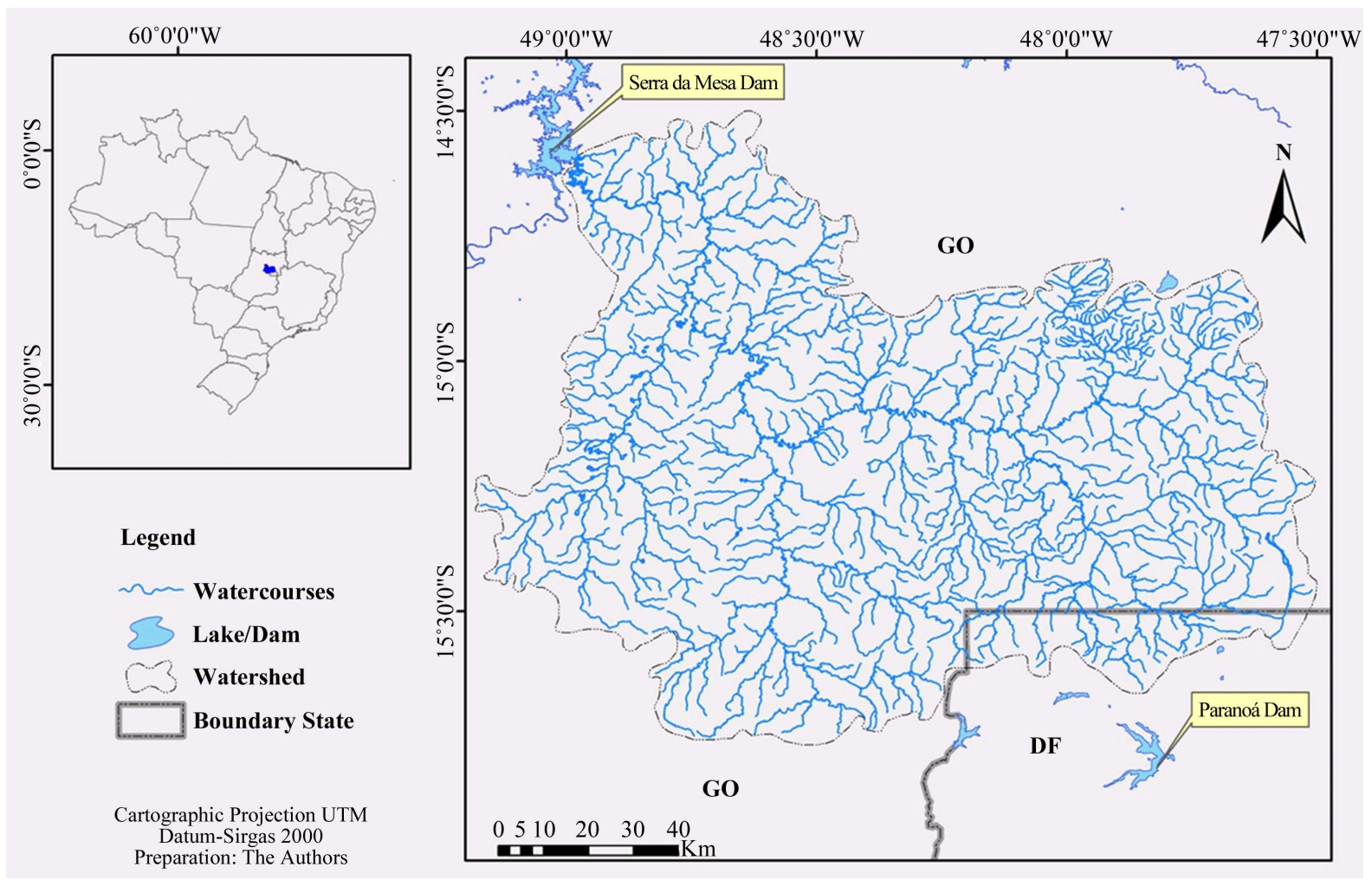

Figure 1. Location of the Maranhão river Basin. 
expressed by the following equation:

$$
R_{b}=N_{u} / N_{u+1}
$$

where: $N$ is the total number of channels in a particular order; and $N_{u+1}$ is the total number of immediately higher order channels.

The drainage density $\left(D_{d}\right)$ describes the total length of channels within a catchment area (in square kilometers). According [2], this parameter represents the hydrological behavior determined by lithology and geological structures, which control the infiltration capacity and behavior of surface channels. The drainage density has an inverse relationship to the river density; thus, when more channels exist, they are less extensive. This quantity is expressed by the following equation:

$$
D_{d}=L_{t} / A
$$

where: $L_{t}$ is the total length of the channels $(\mathrm{km})$, and $A$ is the total basin area $(\mathrm{sq} / \mathrm{km})$.

The river density $\left(D_{r}\right)$ reflects the relationship between the number of streams and the area of a basin. This parameter is related to a basin's ability to generate new fluids. This quantity is expressed by the following equation:

$$
D_{r}=N / A
$$

where:

$N$ represents the total number of rivers or channels, and $A$ is the area of the basin $\left(\mathrm{km}^{2}\right)$.

The extension of the surface route $\left(E_{p s}\right)$ parameter is the average distance traveled by a flood between the interfluve and the permanent river. This variable is important because it represents the link between the hydrological and physiographic development of a drainage network. This quantity is expressed by the following equation:

$$
E_{p s}=1 / 2 D_{d}
$$

where:

$E_{p s}$ is the extent of the surface route, and $D_{d}$ is the drainage density.

The basin area $(A)$ represents the entire area drained by a river system and is generally expressed in square kilometers. This ratio can be measured using conventional methods or more sophisticated methods using specific software.

The length of the entire channel $(L)$ is distinguished from the length of each order of channels by the letter $u$. The sum of the lengths of each order of channels is $L_{u}$, and $L_{t}$ represents the total length of all water bodies in a river basin.

The sinuosity index of channels $\left(I_{s}\right)$ relates the true length of the channels with the straight length between their extreme points. This parameter includes the influence of sediment load and the lithological and structural subdivisions [26]. This quantity is expressed by the following equation:

$$
I_{s}=L / D_{v}
$$

where:

$L$ is the channel length $(\mathrm{km})$;

$D_{v}$ is the vector distance $(\mathrm{km})$ between the extreme points of the same channel.

Values close to 1 indicate high structural control (high energy), and values above 2 indicate low power; intermediate values generally characterize transitional forms between straight and meandering channels.

In this study, we selected slope classes based on the work of [27], as shown in Table 1. This table summarizes the relationships between the slope angle, expressed in degrees $\left({ }^{\circ}\right)$, and the morphology, erosion and possible anthropogenic activities, providing an objective basis for classifying relief.

We added a classification of six levels of use to the class table [27]: high, high with limitations, moderate, moderate with restrictions, partly restricted and restricted. This classification indicates the amount and type of permissible activities in each class.

Our methodology was based on a spatial analysis of the information layers (PIs) in a geographic information 
Table 1. Relationship between slope, morphology, erosion processes, anthropogenic activity and suitability.

\begin{tabular}{|c|c|c|c|c|c|}
\hline Class & Slope Angle & Landform & Process Erosion & Activities & Suitability $^{*}$ \\
\hline 1 & $0^{\circ}-2^{\circ}$ & $\begin{array}{l}\text { Floodplains, terraces, and } \\
\text { surface erosion. }\end{array}$ & $\begin{array}{c}\text { Minimal soil loss and no } \\
\text { landslides }\end{array}$ & $\begin{array}{l}\text { Mechanized agriculture, } \\
\text { urbanization, and roads. }\end{array}$ & High \\
\hline 2 & $2.1^{\circ}-5^{\circ}$ & $\begin{array}{l}\text { Soft ripples, valley bottoms, } \\
\text { and tabular surfaces. }\end{array}$ & $\begin{array}{l}\text { Start of solifluction, diffuse } \\
\text { and laminar flow; furrows. }\end{array}$ & $\begin{array}{l}\text { Some conservation farming. } \\
\text { Acceptable for urbanization. }\end{array}$ & $\begin{array}{l}\text { High with } \\
\text { limitations }\end{array}$ \\
\hline 3 & $5.1^{\circ}-15^{\circ}$ & $\begin{array}{l}\text { On hillsides, monoclines, } \\
\text { and structural reliefs. }\end{array}$ & $\begin{array}{l}\text { Mass movements, creeping } \\
\text { laminar flow, landslides, } \\
\text { furrows, and ravines. }\end{array}$ & $\begin{array}{l}\text { Moderate to intense conservation } \\
\text { farming. Mechanization } \\
\text { impossible }>7^{\circ} \text {. Poorly suited for } \\
\text { urbanization and } \\
\text { infrastructure routes. }\end{array}$ & Moderate \\
\hline 4 & $15.1^{\circ}-25^{\circ}$ & $\begin{array}{l}\text { Mountainous slopes, escarpment } \\
\text { failures and terraces. }\end{array}$ & $\begin{array}{l}\text { Strong linear erosion, soil } \\
\text { destruction, landslides and } \\
\text { falling blocks. }\end{array}$ & $\begin{array}{l}\text { Farming and forestry. Unfit for } \\
\text { urbanization and infrastructure. }\end{array}$ & $\begin{array}{l}\text { Moderate } \\
\text { with } \\
\text { restrictions }\end{array}$ \\
\hline 5 & $25.1^{\circ}-35^{\circ}$ & $\begin{array}{l}\text { Hogback-type structural relief, } \\
\text { coastal cliffs, and ridges. }\end{array}$ & $\begin{array}{c}\text { Strong linear erosion, } \\
\text { destruction of soil, } \\
\text { landslides, falling blocks, } \\
\text { and avalanches. }\end{array}$ & Forest use. & $\begin{array}{l}\text { Partly } \\
\text { restricted }\end{array}$ \\
\hline 6 & $>35^{\circ}$ & $\begin{array}{c}\text { Walls and cliffs in canyons or } \\
\text { very enclosed valleys, and } \\
\text { cornices. }\end{array}$ & $\begin{array}{l}\text { Mass falls, landslides, and } \\
\text { collapses. }\end{array}$ & Limited forest use. & Restricted \\
\hline
\end{tabular}

Text adapted from [27]; ${ }^{*}$ indicates added text or emphasis.

system: a) topography, b) geomorphology, c) drainage channels, d) slope, and e) ecological economic zoning. The data contained in these layers provided in information to support the final analysis.

\section{Results and Discussion}

Table 2 shows morphometric data for the drainage basin based on the Strahler classification of drainage channels, the channel bifurcation ratio $\left(R_{b}\right)$, the average length of the channels in a row $(L)$ and the ratio of the average length of the channels in different hierarchies (MLR).

The basin includes significant numbers of first- and second-order channels, indicating that the drainage headwaters have caused intense dissection of relief. The channel bifurcation ratio is slightly greater than 2 , suggesting a relief configuration with a general hilly trend.

Graphing the relationship between the number of channels and the hierarchical order of the streams that constitute the basin (Figure 2) reveals that Horton's law regarding the number of channels is applicable. According to this law, the number of successively lower-order segments of a given drainage basin tends to form a geometric progression. This progression begins with the single segment of a higher order (the 9th order in this basin) and then increases at a constant ratio. For the scale used in the study $(1: 250,000)$, the $r^{2}$ indicates a $65 \%$ correlation between the number of channels and the hierarchical order.

Understanding the implications of this bifurcation ratio $\left(R_{b}\right)$ for relief and, thus, anthropogenic use is of paramount importance when characterizing the environmental fragility of lower-order waterways. For hydrogeomorphological management, awareness of the intense processes of natural and anthropogenic erosion in the basin's headwaters is required. This is especially important in the Maranhão River Basin, which includes more than 690 first-order channels, representing $49.3 \%$ of the basin's channels.

Board 1 shows the other major indices that were important inputs for creating the suitability classes: the drainage density $\left(D_{d}\right)$, river density $\left(D_{r}\right)$, and extension of the surface route $\left(E_{p s}\right)$. For the Maranhão River Basin, the drainage density and river density are relatively low, indicating lower relief. Thus, other elements must be observed outside the area for a hydrographic basin of this size.

The morphometric parameters of the main drainage channel can helpcharacterize the river basin. Among these, the sinuosity index $\left(I_{s}\right)$ is the relationship between the channel length and the vector distance from the ends of the main channel. When $I_{s} \cong 1.0$, the channel tends to be straight, whereas when $I_{s}>2.0$, the channel tends to be tortuous.

Intermediate values of $I_{s}$ indicate transitional, regular and irregular shapes. Sediment load, lithology, geological structures and channel slope all influence the sinuosity of the channels. 


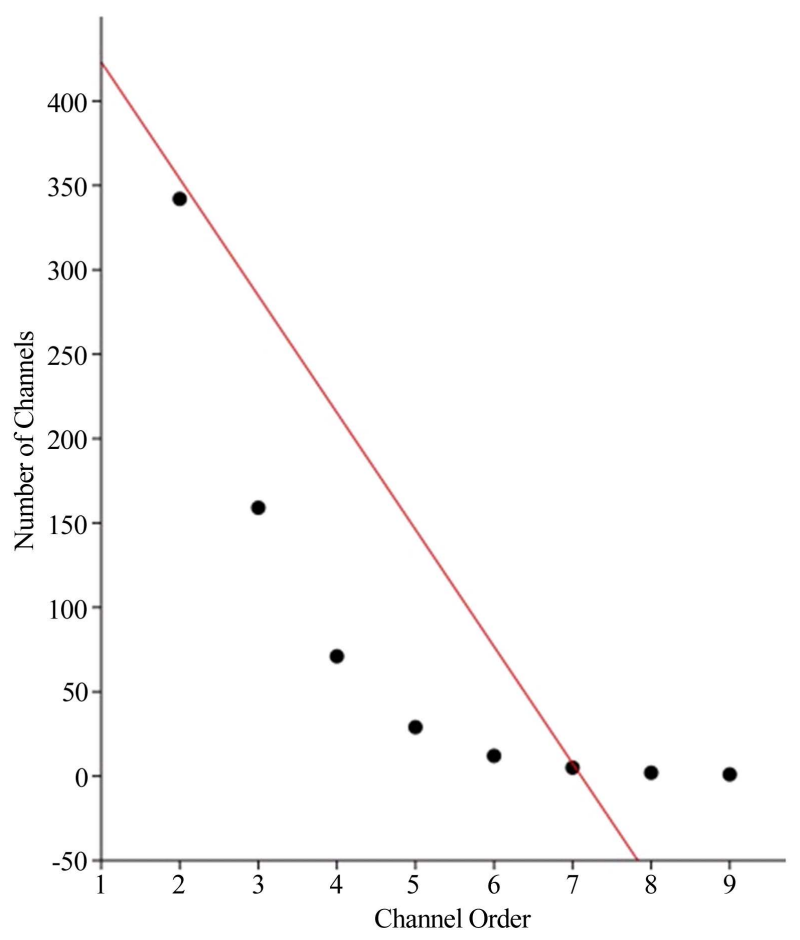

Figure 2. Relationshipbetweenthe number of channelsand the hierarchical order.

Table 2. Basic morphometric parameters of drainage.

\begin{tabular}{|c|c|c|c|c|}
\hline Order & Number of segments & $R_{b}$ & $L(m)$ & $R_{l m}$ \\
\hline \multirow[t]{2}{*}{1} & 693 & & 2.288 & \\
\hline & & 2.02 & & 1.51 \\
\hline \multirow[t]{2}{*}{2} & 342 & & 3.501 & \\
\hline & & 2.15 & & 1.04 \\
\hline \multirow[t]{2}{*}{3} & 159 & & 3.643 & \\
\hline & & 2.23 & & 1.29 \\
\hline \multirow[t]{2}{*}{4} & 71 & & 4.732 & \\
\hline & & 2.44 & & 0.91 \\
\hline \multirow[t]{2}{*}{5} & 29 & & 4.317 & \\
\hline & & 2.41 & & 1.20 \\
\hline \multirow[t]{2}{*}{6} & 12 & & 5.213 & \\
\hline & & 2.40 & & 0.89 \\
\hline \multirow[t]{2}{*}{7} & 5 & & 4.680 & \\
\hline & & 2.5 & & 0.98 \\
\hline \multirow[t]{2}{*}{8} & 2 & & 4.590 & \\
\hline & & 2 & & 2.08 \\
\hline 9 & 1 & & 9.560 & \\
\hline
\end{tabular}

Board 1. General morphometric parameters of the Maranhão River Basin’s hydrography.

\begin{tabular}{cccc}
\hline \multicolumn{3}{c}{ Morphometric parameters } \\
\hline$D_{d}=0.444$ & $D_{r}=0.084$ & $E_{p s}=1.126$ meters & $I_{c}=0.330$ \\
\hline
\end{tabular}


The longitudinal profile of the main channel shows its slope (Figure 3). The profile is balanced, with no sharp drops in slope. It is gently concave, and the slope is steeper in the drainage headwaters. The profile was divided into three sections in which the $I_{s}$ values increasing with distance from the headwaters: the upper third has $I_{s}=$ 1.23 , the middle third has $I_{s}=1.48$, and the lower third has $I_{s}=2.58$. For the entire channel, $I_{s}=2.12$.

The geomorphological map of Maranhão River Basin was adapted from the work of [28] who examined the effect of morphostructural processes on the distribution of features in the basin. In this study, we considered features with high degrees of dissection and, thus, higher relief to correspond to areas that should be subject to more restrictive use.

After comparing the PIs, we created a suitability relief map showing the distribution of slope classes associated with the geomorphological map and other spatial information (Figure 4). We examined the data to verify where human activities are now occurring with respect to these classes (Table 3). We used maps of Cerrado vegetation remnants, which included spatial data on anthropogenic uses of the basin (agriculture, cultivation and urban pasture).

Anthropogenic use corresponds to $25.67 \%$ of the area of the basin and is distributed among the suitability classes, indicating a high degree of control over the relief (Figure 5). In total, $70 \%$ of the anthropogenic use is concentrated in classes 2 and 3. Clearly, the difficulties imposed by high-relief areas impact use because less than $10 \%$ of the anthropogenic use occurs in areas classified with restrictions.

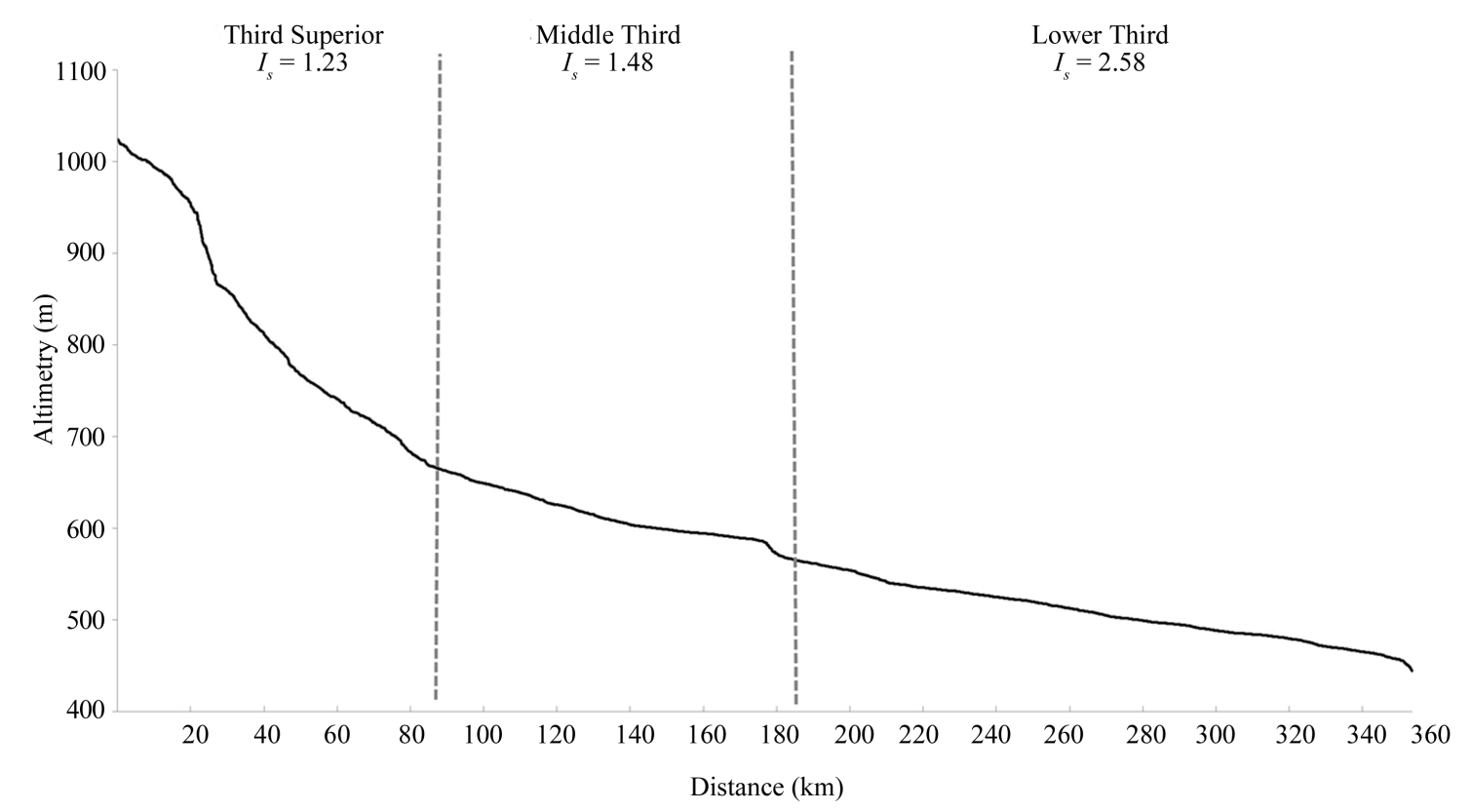

Figure 3. Longitudinal profile of themain channel.

Table 3. Suitability classes, occupied area and percentage of the Maranhão River Basin, anthropogenicuse byclass and anthropogenicuse percentage in each class.

\begin{tabular}{cccccc}
\hline Class & Area $\left(\mathrm{km}^{2}\right)$ & \% in basin & Suitability & Anthropogenic use $\left(\mathrm{km}^{2}\right)$ & $\%$ in class \\
\hline 1 & 2022.52 & 13.1 & High & 760.34 & 37.6 \\
2 & 4181.42 & 26.9 & High with limitations & 1514.48 & 36.2 \\
3 & 5827.92 & 37.4 & Moderate & 1344.65 & 23.1 \\
4 & 2175.47 & 14.0 & Moderate with restrictions & 273.61 & 12.5 \\
5 & 896.89 & 5.7 & Partly restricted & 81.08 & 9.0 \\
6 & 449.97 & 2.9 & Limited & 21.45 & 4.7 \\
\end{tabular}




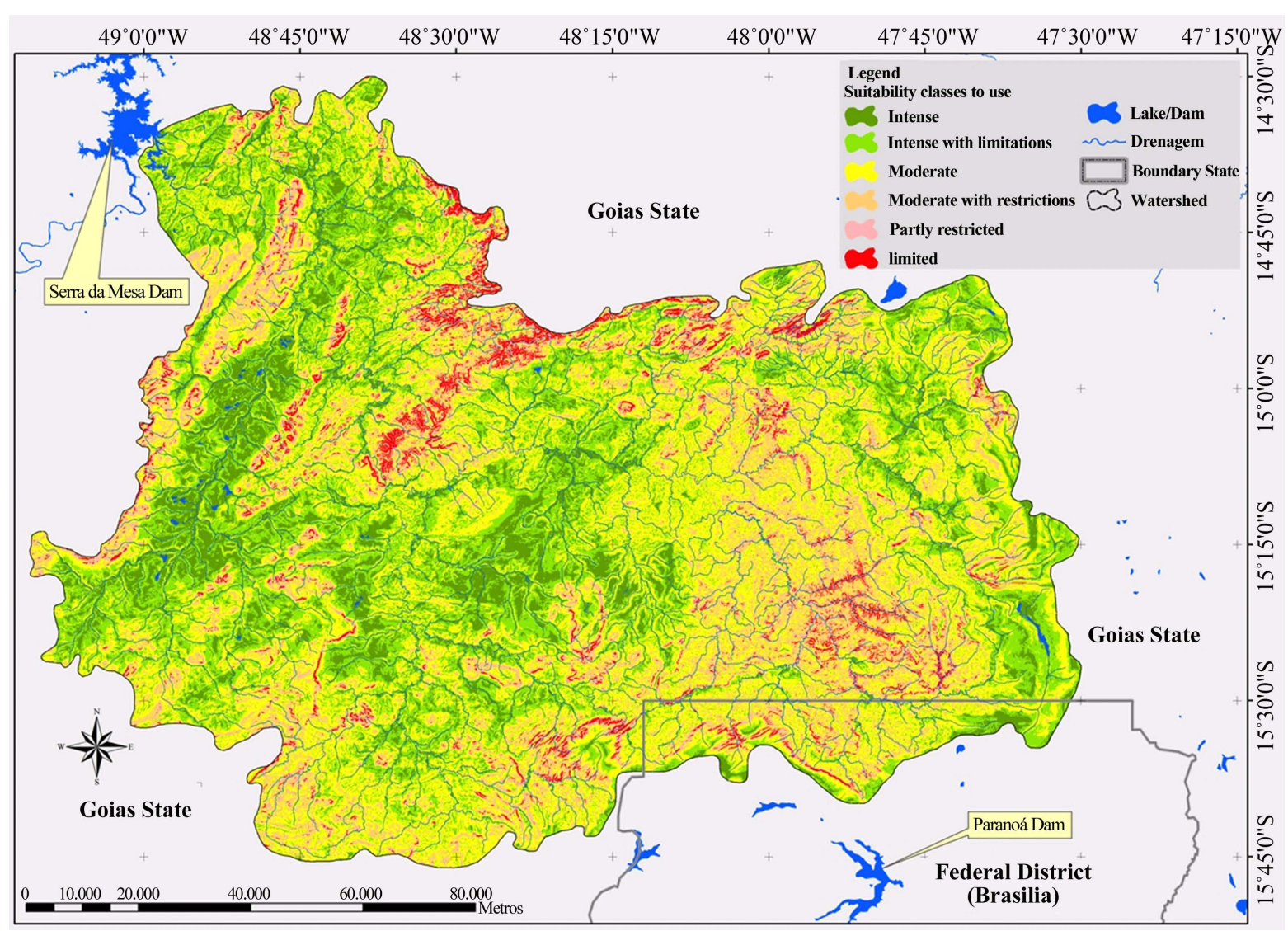

Figure 4. Map of the suitability of the Maranhão River Basin for anthropogenic use.

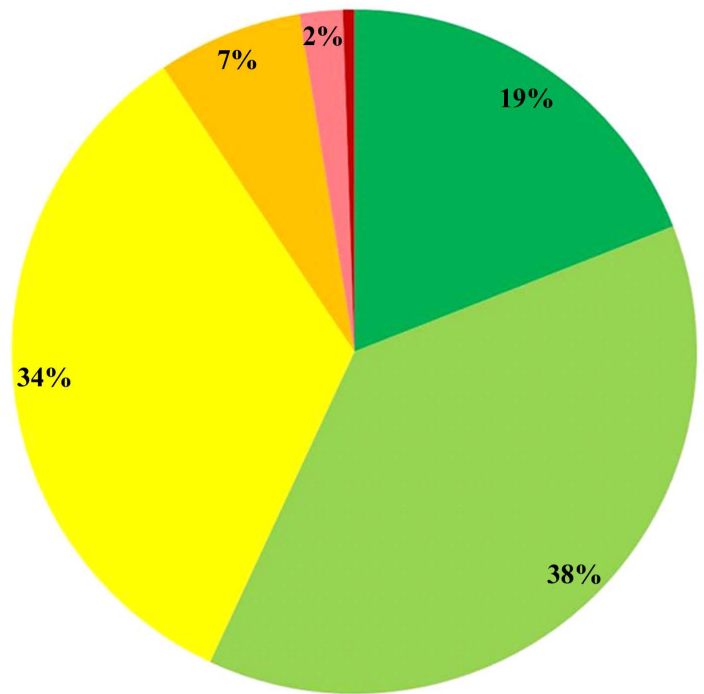

-Class 1 - Intense

ॠ Class 2 - Intense with Limitations

Class 3 - Moderate

Class 4 - Moderate with Restrictions

- Class 5 - Partly Restricted

- Class 6 - Limited

Figure 5. Percentage ofcurrentanthropogenicuse byproposedsuitability class.

The classes proposed in this study were compared with the suitability classes from the Economic Ecological Zoning (ZEE) of the State of Goiás and the Distrito Federal (Table 4). We aimed to verify the possibility of including morphometric indicators in feasibility, economic and ecological studies.

Table 4 shows that the proposed suitability classes exhibit a greater degree of detail than the classes listed in the ZEE. More notably, though, the ZEE suggests that $78 \%(43 \%+35 \%)$ of the basin is suitable for intensive 
Table 4. Comparisonof the suitability classes proposedin this workwith the classeslisted in the ZEE.

\begin{tabular}{ccccc}
\hline Class & Area $\left(\mathrm{km}^{2}\right)$ & Suitability & Proposed (\%) & Listed in the ZEE (\%) \\
\hline 1 & 2022.52 & High & 13.1 & 43.0 \\
2 & 4181.42 & High with limitations & 26.9 & 35.0 \\
3 & 5827.92 & Moderate & 37.4 & --- \\
4 & 2175.47 & Moderate with restrictions & 14.0 & 1.0 \\
5 & 896.89 & Partly restricted & 5.7 & -- \\
6 & 449.97 & Limited & 2.9 & 21.0 \\
\hline
\end{tabular}

anthropogenic use. In contrast, based on morphometric parameters, this percentage is at most $40 \%(13.1 \%+$ $26.9 \%$ ). Furthermore, the ZEE indicates that $21 \%$ of the area should be considered to be restricted, whereas the morphometric approach includes three levels of restricted activity affecting $22.6 \%$ of the area.

We conclude that applying morphometric analysis of the basin to determine the suitability of areas for anthropogenic use represents an improvement over previous methods because it results in a higher level of detail. In addition, it highlights some inconsistencies in the ZEE results.

\section{Conclusions}

This study sought to use spatial analysis to determine the suitability of land in a watershed for anthropogenic use. Spatial analysis of the morphometric parameters of a basin can support qualitative analysis, and this method could be incorporated into the zoning process. We suggest that this quantitative approach is necessary in the context of determining subsidies for territorial development and environmental management procedures.

It highlights the contribution of morphometric measures extracted in the scale of 1:250,000 in particular where articulated with the geomorphological features for a proposed new regional configuration of class stated for the land uses according to the degree of impact they can generate.

This text certainly is a landmark for future studies in the same watershed in more detailed scales, which may further contribute to the sustainable planning for the anthropic uses.

\section{Acknowledgements}

The authors thank their institutions Education and Research (UNB and UEPG) the opportunity to develop a collaborative work carried out under the technical cooperation agreement in the 2012 period to 2015.

\section{References}

[1] Cassetti, V. (1991) Introdução à Geomorfologia. Contexto, São Paulo. (In Portuguese)

[2] Christofoletti, A. (1980) Geomorfologia. 2nd Edition, Blucher, São Paulo.

[3] Lima, W.P. (1996) Introdução ao manejo de bacias hidrográficas. IPEF, São Paulo. (In Portuguese)

[4] Strahler, A.N. (1964) Quantitative Geomorphology of Drainage Basins and Channel Networks. In: Chow, V.T., Ed., Handbook of Applied Hydrology, McGraw-Hill, New York, Section 4-11.

[5] Schumm, S.A. (1956) Evolution of Drainage Systems and Slopes in Badlands at Perth Amboy, New Jersey. Geological Society of America, 67, 597-646. http://dx.doi.org/10.1130/0016-7606(1956)67[597:EODSAS]2.0.CO;2

[6] Christofoletti, A. (1978) Morfologia de bacias de drenagem. Not Geomorfol, 18, 130-132. (In Portuguese)

[7] Horton, R.E. (1932) Drainage-Basin Characteristics. Transactions: American Geophysical Union, 13, 348-352. http://dx.doi.org/10.1029/tr013i001p00350

[8] Horton, R.E. (1945) Erosional Development of Streams and Their Drainage Basins; Hydrophysical Approach to Quantitative Morphology. Geological Society of America Bulletin, 56, 275-370. http://dx.doi.org/10.1130/0016-7606(1945)56[275:EDOSAT]2.0.CO;2

[9] Leopold, L.B. and Maddock, T. (1953) The Hydraulic Geometry of Stream Channels and Some Physiographic Implications. USGS Professional Paper No. 252, 1-57. 
[10] Strahler, A.N. (1957) Quantitative Analysis of Watershed Geomorphology. Transactions: American Geophysical Union, 38, 913-920. http://dx.doi.org/10.1029/tr038i006p00913

[11] Krishnamurthy, J., Srinivas, G., Jayaram, V. and Chandrasekhar, M.G. (1996) Influence of Rock Type and Structure in the Development of Drainage Networks in Typical Hard Rock Terrain. ITCJ, 3, 252-259.

[12] Lana, C.E. and Castro, P.T.A. (2006) Resposta da rede de drenagem à heterogeneidade geológica em bacias hidrográficas: Uma comparação entre bacias do alto rio das Velhas e Jequitiá-MG. In: Goiânia, Ed., Simpósio Nacional de Geomorfologia, Vol. 6, CD-ROM. (In Portuguese)

[13] Ross, J.L.S. (2000) Geomorfologia: Ambiente e planejamento. 5th Edition, Contexto, São Paulo. (In Portuguese)

[14] Mendonça, J.K.S., Mendes, M.R., Alves, I.S., Guerra, A.J.T. and Feitosa, A.C. (2002) Mapeamento e Monitoramento dos Processo Erosivos no Município de São Luís/MA. Simpósio Nacional de Geomorfologia 9, CD-ROM. (In Portuguese)

[15] Nunes, B., De, A., Ribeiro, M.I., De, C., de Almeida, V.J. and Natali Filho, T. (1994) Manual técnico de geomorfologia. IBGE, Rio de Janeiro. (In Portuguese)

[16] Lupinacci, C.M., Mendes, I.A. and Sanchez, M.C. (1999) Análise morfométrica do relevo: O caso da alta bacia do rio Passa Cinco (SP). Simpósio Brasileiro de Geografia Física Aplicada, 7, 141-143. (In Portuguese)

[17] De Biasi, M. (1970) Cartas de declividade: Confecção e utilização. Geomorphology, 21, 8-12. (In Portuguese)

[18] Sanchez, M.C. (1993) A propósito das cartas de declividade. Simpósio Brasileiro de Geografia Física Aplicada, 5, 311-314. (In Portuguese)

[19] Spiridonov, A.I. (1981) Princípios de la metodologia de las investigaciones de campo y el mapeo geomorfológico. Habana. Dissertação (Mestrado em Geografia), Faculdad de Geografia, Universidad de la Habana. (In Spanish)

[20] Mauro, C.A. (1991) Contribuição ao planejamento ambiental de Cosmópolis-SP. Encuentro de Geógrafos de América Latina, 4, 391-419. (In Portuguese)

[21] Mendes, I.A. (1993) A dinâmica erosiva do escoamento pluvial na bacia do córrego. Tese. Lafon, Araçatuba-SP. 264 f (Doutorado em Geografia Física)—FFCHL, Universidade de São Paulo, São Paulo. (In Portuguese)

[22] Hubp, J.I.L. (1988) Elementos de Geomorfologia Aplicada: Métodos Cartográficos. Instituto de Geografia, Mexico. (In Spanish)

[23] Sematec (1993) Mapa Ambiental do Distrito Federal. Secretaria de Meio Ambiente, Ciência Tecnologia—Sematec. Caesb e Codeplan, Brasília. (In Portuguese)

[24] Christofoletti, A. (1969) Análise morfométrica de bacias hidrográficas. Not Geomorfol, 18, 35-64. (In Portuguese)

[25] Cherem, L.F. (2008) Análise morfométrica da bacia do Alto Rio das Velhas-MG. (Dissertação) Mestrado em Modelagem de Sistemas Ambientais. Instituto de Geociências. Universidade Federal de Minas Gerais, IGC/UFMG, Belo Horizonte. (In Portuguese)

[26] Alves, J.M.P. and Castro, P.T.A. (2003) Influência das feições geológicas na morfologia da bacia do rio do Tanque (MG) baseada no estudo de parâmetros morfométricos e análise de padrões de lineamentos. Revista Brasileira de Geociências, 33, 117-124. (In Portuguese)

[27] Granell-Perez, M.C. (2001) Trabalhando geografia com as cartas topográficas. Unijuí, Ijuí. (In Portuguese)

[28] Latrubesse, E.M., Carvalho, T.M., Stevaux, J.C., Moreira, O.L.M. and Rodrigues, P.A. (2005) Geomorfológico de Goiás e distrito. In: Simpósio de Geologia do Centro-Oeste, 9, 2005, Goiânia, Anais, Gioânia: UFG. (In Portuguese) 